ppi $201502 Z U 4645$

Esta publicación científica en formato digital es continuidad de la revista impresa ISSN-Versión Impresa 0798-1406 / ISSN-Versión on line 2542-3185Depósito legal pp $197402 Z$ U34

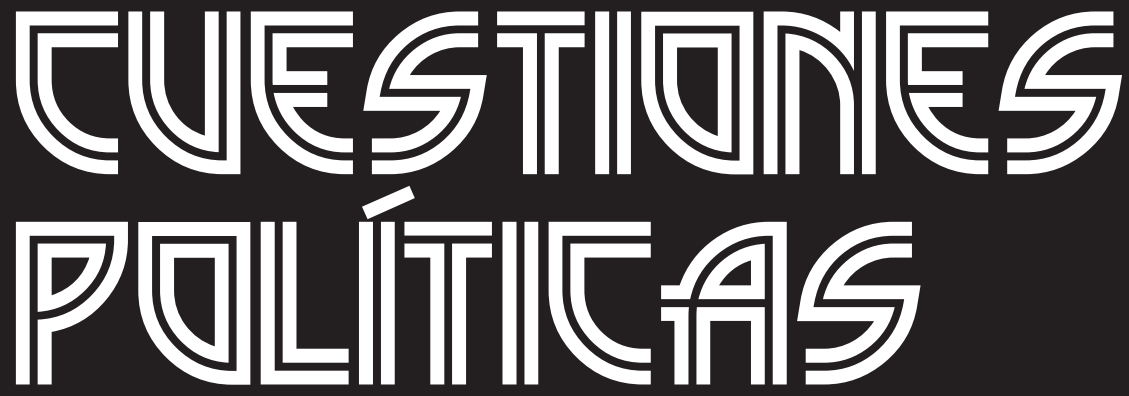

Instituto de Estudios Políticos y Derecho Público "Dr. Humberto J. La Roche" de la Facultad de Ciencias Jurídicas y Políticas de la Universidad del Zulia Maracaibo, Venezuela
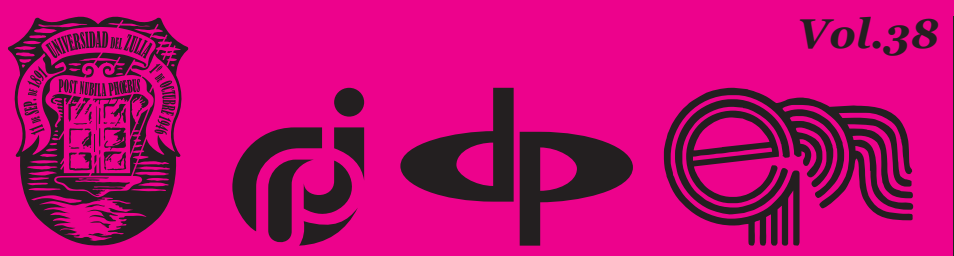

$N^{\circ}$ Especial 1era Parte 2020 


\title{
Creation of the Institute of Medical Law as its Sub-Institute (Sub-Directorate) in the Legal System of Ukraine
}

\author{
DOI: https://doi.org/10.46398/cuestpol.38e.17
}

\author{
Oksana V. Gorbach * \\ Iryna S. Yaroshenko ** \\ Vadim O. Skoryk ***
}

\section{Abstract}

The current stage of training and development of medical law is characterized by discussions on the allocation of medical law in a separate law institute, all in the context of the global COVID-19 crisis. This article aims to identify the concept of medical law institute, including the justification for the need to establish a medical law institution and the consideration of sub-institutes (sub-branches) of medical law. The main method for the study of this topic was the method of analysis, which allows to comprehensively consider the sub-institutes of medical law and the reasons for the separation of the institute of medical law. The document presents the classification of the drug circulation sub-institute (sub-branch) and reveals the components of the structure of medical law. In conclusion, it highlights that, the formation and development of medical law must be based on the following principles: first, it must have the essential characteristics of the law; and, secondly, it must arise and exist in the field of medical professional activity: in the science, practice, ethics and deontology of medical personnel, the rules and procedures of medical institutions.

Keywords: health sector in Ukraine; pharmaceutical activity; medical law; legal system; sub-institute.

* Associate Professor, Candidate of Legal Sciences, Professor of the Department of Public Management and Administration, National Academy of Internal Affairs, Ukraine. ORCID ID: https://orcid. org/oooo-0001-6394-7013. Email: oks.gorbach7@uohk.com.cn

** Associate Professor, Candidate of Legal Sciences, Professor of the Department of Civil and Labour Law, Kyiv National Economic University named after Vadym Hetman, Ukraine. ORCID ID: https://orcid. org/oooo-0oo2-0598-o875. Email: yaroshenko_irina@uohk.com.cn

*** Associate Professor, Candidate of Legal Sciences, Professor of the Department of Public Management and Administration, National Academy of Internal Affairs, Ukraine. ORCID ID: https://orcid. org/oooo-0oo2-7347-4552. Email: skoryk17@tanu.pro 


\section{Creación del Instituto de Derecho Médico como su Sub-Instituto (Subdirección) en el Sistema Legal de Ucrania}

\section{Resumen}

La etapa actual de formación y desarrollo del derecho médico se caracteriza por discusiones sobre la asignación del derecho médico en un instituto de derecho separado, todo ello en el marco de la crisis mundial del COVID-19. Este artículo tiene como objetivo identificar el concepto de instituto de derecho médico, incluida la justificación de la necesidad de establecer una institución de derecho médico y la consideración de los sub-institutos (subramas) del derecho médico. El método principal para el estudio de este tema fue el método de análisis, que permite considerar de manera integral los sub-institutos de derecho médico y los motivos para la separación del instituto de derecho médico. El documento presenta la clasificación del sub-instituto de circulación de medicamentos (sub-rama) y también da a conocer los componentes de la estructura del derecho médico. Como conclusión destaca que, la formación y desarrollo del derecho médico debe basarse en los siguientes principios: en primer lugar, debe tener las características esenciales del derecho; y, en segundo lugar, debe surgir y existir en el ámbito de la actividad profesional médica: en la ciencia, la práctica, la ética y la deontología del personal médico, las normas y procedimientos de las instituciones médicas.

Palabras clave: sector sanitario en Ucrania; actividad farmacéutica; derecho medico; ordenamiento jurídico; sub-instituto.

\section{Introduction}

This paper is directed at identifying the concept of medical law institute, including justification of the necessity for the establishment of a medical law institution and consideration of the sub-institutes (sub-branches) of medical law. The paper suggests the author's approach to the creation of the medical law institute, which is the basis for developing the most promising directions of development of the domestic legislation in this area (Kerimov et al., 2015; Kerimov et al., 2018a).

The work concept is based on the use of general scientific and specialscientific methods and techniques of scientific cognition. Historical and legal method allowed to determine the preconditions of the emergence of the medical law institution as a structural element of the law system, characterized by a set of legal provisions governing the kind of homogeneous 
social relations in the medical industry, as well as the formation of scientific and theoretical views on nature, problems with the establishment of the medical law institute. The comparative legal method was used to compare doctrinal approaches to the establishment and development of the medical law institute. The system-structural method contributed to the awareness of the separation of sub-institutes (sub-branches) of medical law, and namely: health care management, public medical and preventive care, medical treatment, paid medical services, etc. The formal legal method has allowed to comprehensively examine the current state of legislative and normative regulation of the medical law institute, identify the shortcomings of its activities, gaps, contradictions and miscalculations, as well as develop recommendations aimed at their elimination (Allalyev, 2019).

The purpose of this article is to substantiate the necessity and feasibility of implementing the medical law institute into the legal system of Ukraine. Also, the authors thoroughly described the structure of medical law and its components (sub-institutions (sub-branches). Medical law is the object of the research. The interest of such national researchers as Stetsenko (2004); Pashkov and Harkusha (2017); Hladun (2013); Babanin and Yasinskyi (2015); Seniuta (2016); Voronenko and Radysh, (2016); Pashkov et al. (2017); Pashkov et al. (2017); Radysh (2007); Strelchenko et al. (2018); Pashkov et al. (2018), etc. In the legal regulation of medical legal relations may be explained by a number of key factors that necessitate the creation of a separate legal institution, the institution of medical law with its sub-institutions (sub-branches), among which the following should be underlined:

- increase in the number of legal acts regulating the health care sector of Ukraine in general and its sub-sectors.

- the need in practical actions of medical and preventive establishments, as they are those facing problems of medical and legal nature the most often.

- legal practice requests, which indicate an increase in the value of special knowledge related to the peculiarities of public administration of medical and pharmaceutical activities.

- raising the level of legal literacy of people in the field of medical treatment, evidenced by the increase in the number of appeals of citizens in the case of poor-quality treatment and poor-quality medicinal products and medical devices (Voronenko and Radysh, 2016).

The empirical basis of the research is based on surveys of 350 health care professionals about the need to distinguish medical law as a separate subinstitute of law, and according to respondents, it allows to: 1) to systematize the standards of medical law in one codified act; 2) determine the legal 
status of health care professionals and establish a system of guarantees of the rights of health care professionals; 3 ) to legislatively improve the provisions regulating the medicinal products circulation procedure in the system of law of Ukraine (Avtonomova et al., 2019; Kerimov et al., 2018b; Kerimov et al., 2018c).

\section{The internal structure of medical law}

Based on the study, it is argued that the system of law is objectively determined by the unity and consistency of the state legal provisions and their division into separate interconnected elements: branches of law, subbranches of law and legal institutions. That is why, in order to substantiate the essence of medical law, it is expedient to determine exactly its system, which should consist of the following elements: medical law provisions; medical law institute; medical law sub-institutes (sub-branches) (Stetsenko, 2004; Ermilova, 2017; Ermilova, 2018).

The said categorization of medical law into the relevant elements is related to the consideration of the internal structure of medical law by "smaller to larger" principle, i.e. from the smallest piece (medical law provision) to the largest (institute and sub-institute (sub-branch) creating together the medical law as a separate branch (Stetsenko, 2004). Thus, the primary element of the medical law system is the provision of medical law, which must be defined as a structural element of the ;aw system, which is defined as a general rule of conduct intended to regulate medical legal relationships, including legal relations in the field of medical treatment, and provided with state coercion.

The specifics of medical law are that as a complex branch, it includes the rules of various branches of law: criminal, civil, administrative, etc. For example, the issue of implementing compulsory measures of a medical nature is regulated by criminal and administrative law provisions. Public administration in health care are regulated generally by administrative law provisions. Civil law regulates relations between patients and health care institutions, health care contracts, etc. (Stetsenko, 2004).

The said provisions should have the following criteria, and namely: a) rules of conduct, which are already enshrined in legal regulations, if they are not fully legalized, but are declarative or not subject to implementation; b) various kinds of social and professional standards which directly regulate the behavior in the health care sector. The institute is the next element of medical law system as the branch. The general theory of law is defined by the law institute as a group of legal provisions that are an integral part of a branch or sub-branch of law and govern homogeneous social relations that are closely interconnected (Strelchenko et al., 2018). 
That is why, in our opinion, the institution of medical law must be understood as a structural element of the system of law, which is characterized by a set of legal provisions governing the kind of homogeneous social relations in the medical industry. The theoreticians of the law define the law system sub-institute (sub-branch) as a system of homogeneous subject-related institutes of a certain branch of law (Gordadze et al., 2018; Zharikov et al., 2018).

Many branches of law have their sub-institutes (sub-branches). Unlike legal institutes, sub-institutes (sub-branches) are not compulsory components of each branch, but they are present in the branch in question. Medical law institute includes the following sub-institutes (sub-branches) of law: health care management; public treatment and prevention; medicinal products circulation; paid medical services, etc. Accordingly, our research considers the medicinal products circulation itself, which is a sub-institute (sub-branch) of medical law as a branch of law. We believe that medical law sub-institute (sub-branch) is the direct element of law system (Strelchenko et al., 2018; Kerimov et al., 2019; Kerimov et al., 2016).

Confirmation of the need in establishing an institution of medical law with its sub-institutes (sub-branches) is that it is medical law that is implemented on the basis of medical practice and ways of regulating of the industry. Accordingly, in medical practice, specific rules of behavior are formed, which are transformed into legal medical standards as a set of rules of conduct in the medical sphere, which are considered as the main source of creation and development of the medical law institution. It is of particular importance in the course of today's reforms that medical law as a branch of law becomes actuality, significance, and is experiencing an important time for itself as its becoming a law institute (Kudabayeva et al., 2015; Kudabayeva et al., 2018).

\section{Medical law as an institution of law}

We had to underline that coherence and development of the medical law institution reflects the development of this public administration, that is, its component, and is the starting point for its development. This position should be confirmed by the objective and subjective factors of the medical law institute development. It should specify the medical law regulation subject, find out its essential features and determine the place of medical law in the legal system of Ukraine among other legal institutions. Issues of legal provision of medical and pharmaceutical activities have recently become of particular relevance in Ukraine. 
This is primarily due to the active development of medical and pharmaceutical industry, the introduction of voluntary health insurance and the development of a regulatory framework for the introduction of compulsory state social health insurance, the introduction of reimbursement of medicines, implementation of the Available Medicine Governmental Program, using the latest medical science advances (transplantology, reproductive technologies, cloning), improvement of administration in the field of health care, etc. The above summarizes the necessity of introducing such a powerful institute of law as medical law with its sub-institutes (subbranches) (Kerimov and Rachinsky, 2016).

Recently, the need for legal protection of patients and doctors, legal support of medical institutions, and the creation of a legislative framework for the health care system reform are all more topical. That need arose due to increased public attention to cases of damage to health due to poor quality of medical care; the emergence of new biomedical technologies (for example, auxiliary reproductive technologies), causing a lot of ethical and legal issues; the necessity of normative and legal support of the initiated reforms in the industry, etc. Scientists emphasize the need to make maximum efforts to create the theoretical foundations and a single concept of medical law, as well as to develop clear positions, not only from the point of view of the theory of law, but also from the practical application of law, approaches to the assessment of relations in the health care as the most important social sphere (Kuznetsov et al., 2018).

Over the past years, the traditional perception of the doctors and pharmacists as artists, and not as a professional, has changed. The development of legislation, the quality control of medical and pharmaceutical assistance, the adverse effects of medical intervention, all of this is far from a complete list of reasons that increase the "legalization" of the profession of doctors and pharmacists, and, accordingly, "legalize" medical law as the institute of law. Today's realities of medical and pharmaceutical practice show clearly that a doctor and pharmacist who does not know their rights and responsibilities and the limits on which responsibility comes must not be admitted to professional activity (Lapidus et al., 2018a; Lapidus et al., 2018b).

To a greater extent, the above applies to the professional medical and pharmaceutical competence (or incompetence) of the health care managers of various ranks in Ukraine. The need for the proper legal competence of this category of doctors and pharmacists is confirmed by various factors, here are the core ones (Strelchenko et al., 2018): health care reform; significant changes in the regulatory framework for regulating the provision of medical care and provision of medines; the introduction of governmental programs to provide medicines for a certain category of patients (Available Medicine Program); fast development of medicine and pharmacy; paid medical 
Oksana V. Gorbach, Iryna S. Yaroshenko y Vadim O. Skoryk

Creation of the Institute of Medical Law as its Sub-Institute (Sub-Directorate) in the Legal System

services at public and municipal treatment and prevention institutions; development of voluntary medical insurance; the opportunity for patients to protect their rights in the provision of medical and pharmaceutical assistance, with all available means, including by way of applying to the court, etc. (Molen, 2017; Lapidus et al., 2018c; Portnova, 2019).

Medical law as an institution of law becomes especially important in the light of the medical reform in Ukraine, with new, legislative and regulatory acts, which regulate the creation of a modern, effective national legal system, are being amended, improved, supplemented and created, enabling Ukraine to integrate into European legal community, to form effective institutions of civil society and to build a truly democratic, social, and lawgoverned state (Voronenko and Radysh, 2016).

Thus, to date, justification of the role and place of medical law in the legal system of Ukraine is absolutely appropriate and urgent. It is worth mentioning that the medical law in European countries is determined differently. For example, in Germany, the structure of medical law includes such components as: treatment law (Arztrecht), pharmaceutical law (Arzneimittelrecht), medical instruments/products law (Medizinproduktrecht), transfusion law (Transfusionsrecht), which are determined by the regulating object. In Poland, medical law is characterized by the rights of patients and the duties of doctors and includes the varieties of legal liability of all subjects of medical legal relationships (Skakun, 2001; Law System Concept, 2019).

In our opinion, the formation and development of medical law should be based on the following principles: firstly, it should have the essential features of law; and secondly, it should arise and exist within the scope of medical professional activity: in science, practice, ethics and deontology of medical workers, the rules and procedures of medical institutions, etc. The coherence and development of the medical law institution reflects the development of this public administration, that is, its component, and is the starting point for its development. This position should be confirmed by the objective and subjective factors of the medical law institute development. It should specify the medical law regulation subject, find out its essential features and determine the place of medical law in the legal system of Ukraine among other legal institutions (Portnova and Portnova, 2019a).

This means that the institution of medical law should have its own peculiarities that determine the method and subject of legal regulation, as well as the system of medical law with its sub-institutes (sub-branches), and legal regulations. The development of the medical law institute is based on medical practice and ways of its regulation. It should be pointed out that during the medical activity specific rules of behavior are transformed into legal medical standards. The basic set of such rules of conduct in the medical field should be considered as the main source of the creation 
and development of the medical law institution (Strelchenko et al., 2018; Portnova and Portnova, 2019b).

Accordingly, there was a need for the creation of a separate legal institution within which this activity would be regulated, namely the medical law institution with its interrelated elements. Today, medical law is the branch of law and a part of the legal science, which becomes relevant in the light of the reforms and is experiencing an important time of its creation as an institution of law. Now, there are sharp discussions on the allocation of medical law in a separate institute of law, with its direct institutions of law determining its place in the system of legal science. Arguing the need for the separation of institutes and sub-institutes of medical law, we must distinguish the system of medical law, i.e., its internal structure (Strelchenko et al., 2018).

\section{Conclusion}

Based on the foregoing, it should be noted that the sub-institute (branch) of medical law is a structural element of the law system, a separate part of the relevant field of law governing certain groups of public relations in health care industry. In our case, such institute (branch) is medicinal products circulation. We believe that the sub-institute (sub-sector) of the medicinal products circulation should be understood as a structural element of medical law, which includes a system of homogeneous relations that regulate pharmaceutical activity, i.e. the development, production, storage, transportation, quality control, import, export, sale and disposal of medicinal products. As we can see, the circulation of medicines is a kind of pharmaceutical activity, which is carried out in the health care industry as "personified" and large-scale specialized business.

The introduction of a new model for financing medical treatment involves preserving the powers of local self-government bodies in the health sector as a whole, and creating opportunities for their full implementation of tasks that are the creation and proper functioning of the medical law institute with its sub-institutes (sub-branches). The Cabinet of Ministers of Ukraine will clearly define the list of services to be provided within a designated institution, completely ensured at the expense of the state budget. 
Oksana V. Gorbach, Iryna S. Yaroshenko y Vadim O. Skoryk

Creation of the Institute of Medical Law as its Sub-Institute (Sub-Directorate) in the Legal System

\section{Bibliographic References}

ALLALYEV, Ruslan. 2019. "Religious origins of the rule of law conception in the United States” In: Amazonia Investiga. Vol. 7, No. 14, pp. 212-217.

AVTONOMOVA, Svetlana; KUTYRKINA, Lyudmila; FEDYUNIN, Dmitry; BEZPALOV, Valery; Lochan, SERGEY. 2019. "GR in the university brand-communications system” In: Amazonia Investiga. Vol. 8, No. 19, pp. $173-178$.

BABANIN, Anatoliy; YASINSKYI, Volodymyr. 2015. Medical law. Publishing house "Antikva". Simferopol, Crimea.

ERMILOVA, Maria. 2017. "Factors limiting the effectiveness of the Russian mortgage system" In: International Relations 2017: Current Issues of World Economy and Politics. Vol. 1, pp. 260-269.

ERMILOVA, Mariia. 2018. "The use of European experience in mortgage lending in Russian conditions" In: International Relations 2018: Current Issues of World Economy and Politics. Vol. 1, pp. 167-175.

GORDADZE, Guram; KERIMOV, Vagif; GIRUTS, Maksym; POSHIBAEVA, Alexandra; KOSHELEV, Vladimir. 2018. "Genesis of the asphaltite of the Ivanovskoe field in the Orenburg region, Russia” In: Fuel. Vol. 216, pp. 835-842.

HLADUN, Zenoviy. 2013. "Content and features of administrative law relations in public health industry" In: Ukrainian Law. No. 10, pp. 241-248.

KERIMOV, Vagif; GORBUNOV, Aleksey; LAVRENOVA, Elena; OSIPOV, Alexander. 2015. "Models of hydrocarbon systems in the Russian Platform-Ural junction zone” In: Lithology and Mineral Resources. Vol. 50, No. 5, pp. 394-406.

KERIMOV, Vagif; GORDADZE, Guram; LAPIDUS, Albert; GIRUTS, Maksym; MUSTAEV, Rustam; MOVSUMZADE, Eldar; ZHAGFAROV, Fyrdaves; ZAKHARCHENKO, Maryia. 2018a. "Physicochemical properties and genesis of the asphaltites of Orenburg oblast" In: Solid Fuel Chemistry. Vol. 52, No. 2, pp. 128-137.

KERIMOV, Vagif; LEONOV, Mikhail; OSIPOV, Alexander; MUSTAEV, Rustam; HAI, Vu. 2019. "Hydrocarbons in the basement of the South China Sea (Vietnam) shelf and structural-tectonic model of their formation" In: Geotektonika. Vol. 53, No. 1, pp. 42-59. 
KERIMOV,Vagif; MUSTAEV, Rustam; BONDAREV,Andrey. 2016. "Evaluation of the organic carbon content in the low-permeability shale formations (as in the case of the Khadum suite in the Ciscaucasia region)" In: Oriental Journal of Chemistry. Vol. 32, No. 6, pp. 3235-3241.

KERIMOV, Vagif; MUSTAEV, Rustam; OSIPOV, Alexander. 2018b. "Peculiarities of hydrocarbon generation at great depths in the crust" In: Doklady Earth Sciences. Vol. 483, No. 1, pp. 1413-1417.

KERIMOV, Vagif; RACHINSKY, Michael. 2016. "Geofluid dynamic concept of hydrocarbon accumulation in natural reservoirs" In: Doklady Earth Sciences. Vol. 471, No. 1, pp. 1123-1125.

KERIMOV, Vagif; RACHINSKY, Mykhayl; MUSTAEV, Rustam; SERIKOVA, Uliana. 2018c. "Geothermal conditions of hydrocarbon formation in the South Caspian basin” In: Iranian Journal of Earth Sciences. Vol. 10, No. 1, pp. 78-89.

KUDABAYEVA, Khatimya; BATYROVA, Gulnara; BAZARGALIYEV, Yerlan; BASPAKOVA, Akmaral; SAKHANOVA, Svetlana. 2018. "Hair trace element composition in 6- to 12-year-old children with goiter in West Kazakhstan, a province of the Republic of Kazakhstan" In: Journal of Elementology. Vol. 23, No. 2, pp. 647-657.

KUDABAYEVA, Khatimya; YERMUKHANOVA, Ludmila; KOSHMAGANBETOVA, Gulbakit; BAZARGALIEV, Yerlan; BASPAKOVA, Akmaral; KALDYBAEV, Keulymzhai; KALDYBAEVA, Aiman. 2015. "Estimation of thyroid gland volume by means of ultrasonography among school children in Aktobe area, Kazakhstan" In: Research Journal of Pharmaceutical, Biological and Chemical Sciences. Vol. 6, No. 2, pp. 87-93.

KUZNETSOV, Nykolai; KERIMOV, Vagif; OSIPOV, Alexander; BONDAREV, Andrey; MONAKOVA, Aleksandra. 2018. "Geodynamics of the Ural foredeep and geomechanical modeling of the origin of hydrocarbon accumulations" In: Geotectonics. Vol. 52, No. 3, pp. 297-311.

LAPIDUS, Albert; KERIMOV, Vagif; MUSTAEV, Rustam; MOVSUMZADE, Eldar; ZAKHARCHENKO, Maryia. 2018a. "Caucasus Maykopian Kerogenous shale sequences: generative potential” In: Oil Shale. Vol. 35, No. 2, pp. 113-127.

LAPIDUS, Albert; KERIMOV, Vagif; MUSTAEV, Rustam; MOVSUMZADE, Eldar; SALIKHOVA, Irina; ZHAGFAROV, Fyrdaves. 2018b. "Natural bitumens: physicochemical properties and production technologies" In: Solid Fuel Chemistry. Vol. 52, No. 6, pp. 344-355. 

Oksana V. Gorbach, Iryna S. Yaroshenko y Vadim O. Skoryk
Creation of the Institute of Medical Law as its Sub-Institute (Sub-Directorate) in the Legal System 276 of Ukraine

LAPIDUS, Albert; KERIMOV, Vagif; TRETYYAKOV, Valentyn; TALYSHINSKII, Rashyd; ILOLOV, Akhmadsho; MOVSUMZADE, Eldar. 2018c. "Extraction of Asphaltite with Toluene" In: Solid Fuel Chemistry. Vol. 52, No. 4, pp. 256-259.

LAW SYSTEM CONCEPT. 2019. Available online. In: https://pidruchniki. com/12191214/pravo/ponyattya_sistemi_prava. Consultation date: $12 / 04 / 2020$.

MOLEN, Iryna. 2017. "Core directions of health care legisltation reformation in Ukraine” In: Actual Problems of Law. Vol. 3, No. 11, pp. 80-85.

PASHKOV, Vitalii; HARKUSHA, Andrii. 2017. “3-D Bioprinting law regulation perspectives” In: Wiadomosci Lekarskie. Vol. 70, No. 3, pp. 480-482.

PASHKOV, Vitalii; HARKUSHA, Andrii; BYTYAK, Oleksiy. 2017. "Advertising of medical devices: Foreign experience and Ukrainian practice" In: Wiadomosci Lekarskie. Vol. 70, No. 3, pp. 456-461.

PASHKOV, Vitalii; OLEFIR, Andrii; BYTYAK, Oleksiy. 2017. "Legal features of the drug advertising" In: Wiadomosci Lekarskie. Vol. 2, No. 28, pp. 1522.

PASHKOV, Vitalii; UDOVYKA, Larysa; DICHKO, Hanna. 2018. "International medical law and its impact on the Ukrainian health care legislation" In: Wiadomosci Lekarskie. Vol. 71, No. 1, pp. 201-205.

PORTNOVA, Irina; PORTNOVA, Tatiana. 2019a. "Stylistic features of European architecture of XX - beginning of XXI century in the light of current trends of the time" In: Journal of Mathematics and Computer Science. No. 1, pp. 51-60.

PORTNOVA, Irina; PORTNOVA, Tatiana. 2019b. "The importance of academic education in contemporary architectural and sculptural practice" In: Journal of Mathematics and Computer Science. No. 1, pp. 518-526.

PORTNOVA, Tatiana. 2019. "Composite-image organization of the dramaturgy of dance based paintings" In: Amazonia Investiga. Vol. 8, No. 20, pp. 415-421.

RADYSH, Yaroslav Fedorovych. 2007. "Medical law is the important academic subject in post-graduate education of Ukrainian doctors" In: Medical law of Ukraine: creation and development problems: materials of the first allUkrainian scientific and applied conference, pp. 248-253.

SENIUTA, Iryna Yaroslavivna. 2016. Medical-law explanatory dictionary. LOBF "Medytsyna \& Pravo" Publishing House. Lviv, Ukraine. 
SKAKUN, Oleksandr Fedorovych. 2001. Theory of state and law. Consum. Kharkiv, Ukraine.

STETSENKO, Semen Hryhorovych. 2004. Medical law. Yuridichesky Center Press. Saint Petersburg, Russia.

STRELCHENKO, Oksana; LYCHENKO, Ihor; SHEVCHENKO, Lyudmyla. 2018. "Doctrinal characteristic of public of medicines as fundamental element of state financial guarantees for the pharmaceutical sphere" In: Baltic Journal of Economic Studies. Vol. 4, No. 5, pp. 338-343.

VORONENKO, Yuriy; RADYSH, Yaroslav. 2016. "Medical law in law system of Ukraine: Current situation and prospectives of development" In: Ukraiinskyi Medychnyi Chasopys. Vol. 5, No. 55, pp. 5-10.

ZHARIKOV, Roman; BEZPALOV, Valerii; LOCHAN, Sergei; BARASHKIN, Maksim; ZHARIKOV, Aleksandr. 2018. "Economic security of regions as a criterion for formation and development of agricultural clusters by means of innovative technologies" In: Scientific Papers Series Management, Economic Engineering in Agriculture and Rural Development. Vol. 18, No. 4, pp. 431-439. 


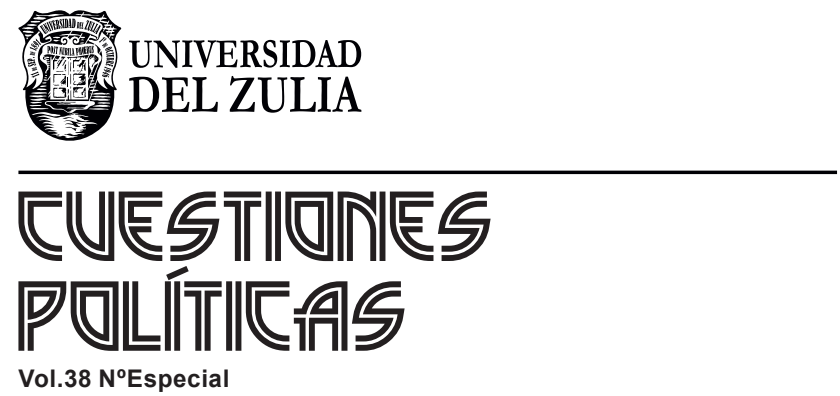

www.luz.edu.ve 